\title{
The Solow Model and Standard of Living
}

Eric Frey

University of South Florida

Advisors:

Arcadii Grinshpan, Mathematics and Statistics

Michael Loewy, Economics

Problem Suggested By: Eric Frey

Follow this and additional works at: https://digitalcommons.usf.edu/ujmm

Part of the Mathematics Commons

UJMM is an open access journal, free to authors and readers, and relies on your support:

Donate Now

\section{Recommended Citation}

Frey, Eric (2017) "The Solow Model and Standard of Living," Undergraduate Journal of Mathematical Modeling: One + Two: Vol. 7: Iss. 2, Article 5.

DOI: http://doi.org/10.5038/2326-3652.7.2.4879

Available at: https://digitalcommons.usf.edu/ujmm/vol7/iss $2 / 5$ 


\title{
The Solow Model and Standard of Living
}

\begin{abstract}
All across the world, living standards vary significantly. The Solow growth model, developed by Nobel Prize winning economist Robert Solow in 1956, is still one of the most commonly used models in economics to explain economic growth. This paper will outline the Solow growth model, and its assertion that increases in total factor productivity (TFP) can lead to limitless increases in the standard of living in a country. Much of the mathematical notation and explanation has been derived from Stephen Williamson of Washington University. Additionally, it will provide empirical examples illustrating the model's ability to match real-world data.
\end{abstract}

\section{Keywords}

economic growth, standard of living, Solow model

Creative Commons License

(c) (i) (अ)

This work is licensed under a Creative Commons Attribution-Noncommercial-Share Alike 4.0 License. 


\section{PROBLEM STATEMENT}

What causes an increase in the living standards of a country?

\section{Motivation}

Some have defined economics as "the study of the choices people make with the limited resources they have." With this in mind, one of the central focuses of economics is economic growth. How is it that some countries utilize their scarce resources and continue to improve the standard of living for their people and others do not? Answering these questions has motivated a great amount of economic study by Robert Solow and others in the field. Through his research, Solow was able to develop a model that consistently matches empirical data as to what causes the standard of living in a country to grow, or decline, over time. The objective of this project is to illustrate his model, and provide empirical examples supporting its relevance.

\section{MATHEMATICAL DESCRIPTION AND SOLUTION APPROACH}

As we develop the environment for the economic model, we will have to make assumptions regarding how the environment will behave. As Solow himself said, "all theory depends on assumptions which are not quite true. That is what makes it theory (Solow 65). This dynamic economic model covers many periods of time; but, "we will analyze the economy in terms of the 'current' and 'future' periods" (Williamson 237). The Solow model begins by describing the consumers who live in our model environment, and the production technology used by the representative firm. Our analysis will be derived through the interaction between the 
consumers, the representative firm, and the production technology present in our model

environment. To make matters easier, our model will not possess a government sector or taxes.

In describing our consumers, there is a growing population of consumers, with

$N$ denoting the population in the current period. Our model does not allow for any unemployment among consumers, so each consumer is part of the labor force employed by the representative firm. Our equation to illustrate population growth of consumers is:

$$
N^{\prime}=(1+n) N
$$

with

$N^{\prime}$

being population in the future period and $n>-1$. Here, $n$ is the rate of population growth; this variable is assumed to be constant over time. Allowing $n<0$ means there could be negative population growth in the future period. $N$ is population in the current period.

"In each period, a given consumer has one unit of time available, and we assume that consumers do not value leisure, so that they supply their one unit of time as labor in each period" (Williamson 237). With the assumption of zero unemployment in this model, $N$ also refers to number of workers in the labor force and $n$ as the labor force growth rate. Using their time towards work allows the population to receive all current real output $(Y)$ of the representative firm as income. $Y$ is created through wage income and dividend income from the representative firm. To simplify matters, we assume consumers use a constant fraction of their income in both periods, as seen in the consumption function:

$$
C=(1-s) Y
$$


The fraction of income saved is notated as $S$. Whatever income $(Y)$ consumers do not spend is saved for the future period, so $Y=C+S$, where $S$ is aggregate savings. From equation (2), it is seen that $s Y=S$.

Our representative firm produces output according to the following production function:

$$
Y=z F(K, N)
$$

In the preceding function, current output $(Y)$ is the product of a function $(F)$ of capital $(K)$ and labor $(N)$, and total factor productivity $(z)$. When capital is discussed in this model, it is in reference to any material goods utilized in production of a good or service, such as machines for sewing clothes, or facilities to house workers. Total factor productivity $(z)$ captures how efficient a firm is at converting inputs $(K, N)$ into real output $(Y)$. Therefore, increases in $z$ allow the firm to utilize less of $K$ and $L$ in the production of each unit of output. In our production function, the assumption of constant returns to scale is made. This means that an additional unit of capital or labor will always provide the same additional amount of labor. For example, if 400 units of labor and 400 units of capital are utilized in the production of $200 \mathrm{t}$-shirts, then 500 units of labor and 500 units of capital will lead to the production of $250 \mathrm{t}$-shirts.

With this assumption of constant returns to scale, Equation (3) is divided by $N$ on both sides to get

$$
\frac{Y}{N}=z F\left(\frac{K}{N}, 1\right)
$$

In equation (4), $\frac{Y}{N}$ is output per worker, which has the same meaning as real income per capita (Williamson 238). With $\frac{K}{N}$ being capital per worker, the assumption of constant returns creates a manipulated production function stating that output per worker only depends on the amount of 
capital per worker. Using lowercase variables to account for per worker values, equation (4) is now rewritten as

$$
y=z f(k)
$$

"where $y$ is output per worker, $k$ is capital per worker, and $f(k)$ is the per-worker production function, which is defined by $f(k) \equiv F(k, 1)$ " (Williamson 238). This per-worker production function is graphed in figure (1). A key property of the per-worker production function is that its slope is the marginal product of capital (MPk), the amount of additional output created by the addition of one unit of capital. Because $f(k) \equiv F(k, 1)$, an additional unit of capital increases the per-worker production function by the MP $k$. "As the slope of the per-worker production function is $\mathrm{MP} k$, and because MP $k$ is decreasing with $K$, the per-worker production function in the figure is concave - that is, its slope decreases as $k$ increases" (Williamson 238).

The Solow model continues with the idea some of the firm's capital stock depreciates at a constant rate, $d$, with $0<d<1$. With this principle, capital stock will change over time. Future period capital stock will follow the equation

$$
K^{\prime}=(1-d) K+I
$$

where $K^{\prime}$ is future period capital stock, $K$ is current period capital stock, and $I$ is investment. In terms of investment, it encompasses money saved by consumers $(S)$ that is invested back into the representative firm. This idea will be discussed further as competitive equilibrium is elaborated on. 
In Economics, a competitive equilibrium occurs when the behavior of consumers and firms result in a market scenario where the output supplied by the firm equals the amount of product demanded by consumers. Thus, it is labeled as equilibrium because the market "clears"consumers have maximized their scarce resources and firms have produced the maximum amount of output they can without any excess in the current market. With the behavior of consumers and the representative firm being described in the prior sections of this work, the focus turns to how these two sides reach a competitive equilibrium in the Solow model.

The Solow model possesses two markets, the labor market and capital market, which must clear in the current period. In the labor market, consumers trade their labor in exchange for current consumption goods (our model does not deal with currency, such as dollar bills). This equilibrium is explained geometrically in Figure (2). In the capital market, consumers trade current consumption goods for capital. "That is, capital is the asset in this model, and consumers save by accumulating it" (Williamson 239). For the capital market to be in equilibrium, the amount of savings by consumers must equal the amount of investment, that is $S=I$. Therefore, capital market equilibrium is when aggregate consumption plus aggregate investment equals current output:

$$
Y=C+I .
$$

Equation (6) can be arranged to $I=K^{\prime}-(1-d) K$. By using this and equation (2) to substitute for $C$ and $I$ in equation (7), it is found that

$$
Y=(1-s) Y+K^{\prime}-(1-d) K .
$$

Equation (8) can be written as: 


$$
K^{\prime}=s Y+(1-d) K
$$

This states that future capital stock $(K)$ is equal to the aggregate savings in the current period, plus the capital stock from the current period - net of depreciation $[(1-d) K]$. Now, by substituting for $Y$ in equation (9) with the production function from equation (3), the function

$$
K^{\prime}=s z F(K, N)+(1-d) K
$$

is derived. This equation "states that the stock of capital in the future period is equal to the quantity of savings in the current period (identical to the quantity of investment) plus the quantity of capital that remains in the future after depreciation" (Williamson 240).

To state equation (10) in per-worker terms, both sides are divided by the number of workers, $N$, to get

$$
\frac{K^{\prime}}{N}=s z \frac{F(K, N)}{N}+(1-d) \frac{K}{N}
$$

After multiplying the left-hand side of equation (11) by $1=\frac{N^{\prime}}{N^{\prime}}$, we get

$$
\frac{K^{\prime}}{N} \frac{N^{\prime}}{N^{\prime}}=S Z \frac{F(K, N)}{N}+(1-d) \frac{K}{N}
$$

For simplicity, Equation 12 can be rewritten as

$$
k^{\prime}(1+n)=\operatorname{szf}(k)+(1-d) k
$$

In (13), $k^{\prime}=\frac{K^{\prime}}{N}$, which is future capital per-worker, $(1+n)=\frac{N^{\prime}}{N}$; and, the first term on the right-hand side of the equation is as such because $\frac{F(K, N)}{N}=F\left(\frac{K}{N}, 1\right)=f(k)$.

Now, to get $k^{\prime}$ by itself on the left-hand-side, both sides of equation (13) are divided by $(1+n):$

$$
k^{\prime}=\frac{s z f(k)}{1+n}+\frac{(1-d) K}{1+n} .
$$


Equation (14) "is a key equation that summarizes most of what we need to know about competitive equilibrium in the Solow growth model, and we use this equation to derive the important implication of the model" (Williamson 240). The equation determines future capital stock per-worker as a function of current capital stock per worker.

Equation (14) is graphed for geometric interpretation in Figure (3). As in Figure (2), the curve in Figure (3) has a decreasing slope due to the decreasing marginal product of capital $\left(\mathrm{MP}_{\mathrm{k}}\right)$. The $45^{\circ}$ line pictured is the line along which $k^{\prime}=k$. The "steady state" of the economy is indicated by the intersection of the $45^{\circ}$ line and the curve. In economics, a steady state is when the economy is in a long-run equilibrium. In the long-run equilibrium, the economy is operating at its maximum attainable capacity, given current knowledge and technology. Figure (3) illustrates that "once the economy reaches the steady state, where current capital per worker $k=$ $k^{*}$, then future capital per worker $k^{\prime}=k^{*}$, and the economy has $k^{*}$ units of capital forever after" (Williamson 241). Again, the significance is an attainable unit of long-run equilibrium. So, if our model economy were to be played out in real life, the economy would never produce less in the long-run than the steady state. Only catastrophic events, such as a natural disaster, civil war (i.e. the current Syria conflict) could lead to a decrease in the steady state value. Geometrically speaking, from Figure (3) it is illustrated that if the current period capital per worker, $k$, is less than the steady state value $\left(k<k^{*}\right)$, then future period capital stock will increase $\left(k^{\prime}>k\right)$ so the steady state is maintained.

For our analysis on increasing standards of living $\left(y^{*}\right.$ in our model $)$, there must be a variable in the Solow model that causes the steady state to continually increase over time. Since the Solow model predicts that capital per worker, $k^{*}$, converges to a constant, it also predicts that output per worker, $y^{*}$, converges to a constant. This can be seen through the per-worker 
production function $y^{*}=z f\left(k^{*}\right)$. Again, with $y^{*}$ representing steady state income per-worker, this is how standard of living is measured in the Solow model.

\section{DISCUSSION}

With the necessary pieces of the model elaborated upon and developed, we now analyze how the steady state is affected by changes in the savings rate $(s)$, population growth rate $(n)$, and total factor productivity $(z)$. In order to do this, we start with the steady state equation, equation (14). Since $k^{\prime}=k=k^{*}$ in the steady state, it follows that

$$
s z f\left(k^{*}\right)-(n+d) k^{*}=0 .
$$

To see how changes in $s, n$, and $z$ affect the steady state quantity of $k^{*}$, equation (15) is totally differentiated:

$$
\left[s z f^{\prime}\left(k^{*}\right)-n-d\right] \mathrm{d} k^{*}+z f\left(k^{*}\right) \mathrm{d} s-k^{*} \mathrm{~d} n+s f\left(k^{*}\right) \mathrm{d} z=0
$$

"Then solving for the appropriate (partial) derivatives, we obtain

$$
\begin{gathered}
\frac{\partial k^{*}}{\partial s}=\frac{-z f\left(k^{*}\right)}{s z f^{\prime}\left(k^{*}\right)-n-d}>0 \\
\frac{\partial k^{*}}{\partial n}=\frac{k^{*}}{s z f^{\prime}\left(k^{*}\right)-n-d}<0 \\
\frac{\partial k^{*}}{\partial z}=\frac{-s f\left(k^{*}\right)}{s z f^{\prime}\left(k^{*}\right)-n-d}>0 "
\end{gathered}
$$

(Williamson 673). As evidenced, capital per worker is positively correlated with $s$ and $z$, but negatively correlated with $n$. This is due to the denominator $\left[s z f^{\prime}\left(k^{*}\right)-n-d\right]$ in our partial derivatives which is of negative value in the steady state. 
While steady state capital per worker $\left(k^{*}\right)$ and, consequently, income per worker $\left(y^{*}\right)$ is increased with increases in the savings rate $(s)$ and total factor productivity $(z)$, only total factor productivity can lead to limitless rises in both (Solow 85). It is easily understood that there is no plausible way for a nation to continuously increase its savings rate (people must consume in the current period); so, Solow concludes that increases in standard of living can only occur continuously through increases in total factor productivity. This assertion is illustrated in Figure (4).

As mentioned earlier, total factor productivity discusses how efficient firms are at converting inputs used into output that can be sold for revenue. There is much empirical evidence to support Solow's assertion that continuous increase in total factor productivity continuously increases the standard of living of people over time. Figure (5) provides economic research from the Federal Reserve Bank of St. Louis, illustrating the strong positive correlation that exists between our measure of standard of living, GDP per capita, and total factor productivity in the United States. Another example of the empirical truths of Solow's assertion is the growth of China. From 1990 - 2008, China led the world in average annual total factor productivity growth at an average annual rate of $4 \%$ (The Economist). Over the same time, China saw, and continues to see, an increase in GDP per capita. This empirical evidence, and another example of the significant correlation between GDP per capita and total factor productivity, is provided in Figure (6). One of the worst recessions in recent history is that of Greece. In Figure (7), a strong correlation is seen again between GDP per capita and total factor productivity. These graphs provide empirical evidence to Solow's assertion that a country's efficiency in converting inputs to output affects the standard of living its people experience. 


\section{CONCLUSION AND RECOMMENDATIONS}

As evidenced through the derivations of the model and empirical analysis, there is much to support Solow's assertion that increases in technological progress lead to limitless increases to standards of living. When a country gains access to items such as smartphones, laptops, education, etc., output begins to get produced more efficiently; and, the people in a given country live more prosperous lives. Economists deal with the study of scarce resources. Solow's model illustrates that the better a country and its people are at efficiently utilizing scarce resources, the more likely it will prosper. 


\section{NOMENCLATURE}

\begin{tabular}{|c|c|c|}
\hline$N$ & 1) Population in current period; 2) Current labor force & \\
\hline$N^{\prime}$ & Population in the future period & \\
\hline$n$ & Population growth rate & $>-1$ \\
\hline$C$ & Consumption in current period & \\
\hline$Z$ & Total factor productivity & \\
\hline$S$ & Aggregate savings & \\
\hline$S$ & Rate of income saved by individuals & $0 \leq s<1$ \\
\hline$Y$ & 1) Current real output; 2) Current consumer income & \\
\hline$K$ & Capital & \\
\hline$y$ & Income per-worker & \\
\hline$k$ & Capital per-worker & \\
\hline$f(k)$ & Per-worker production function & \\
\hline$Y=z F(K, N)$ & Production function & \\
\hline$d$ & Depreciation rate of capital & $0<d<1$ \\
\hline$K^{\prime}$ & Future capital stock & \\
\hline$I$ & Aggregate Investment & \\
\hline
\end{tabular}




\section{Appendices}

Figure 1: The Per-Worker Production Function (Williamson 239)

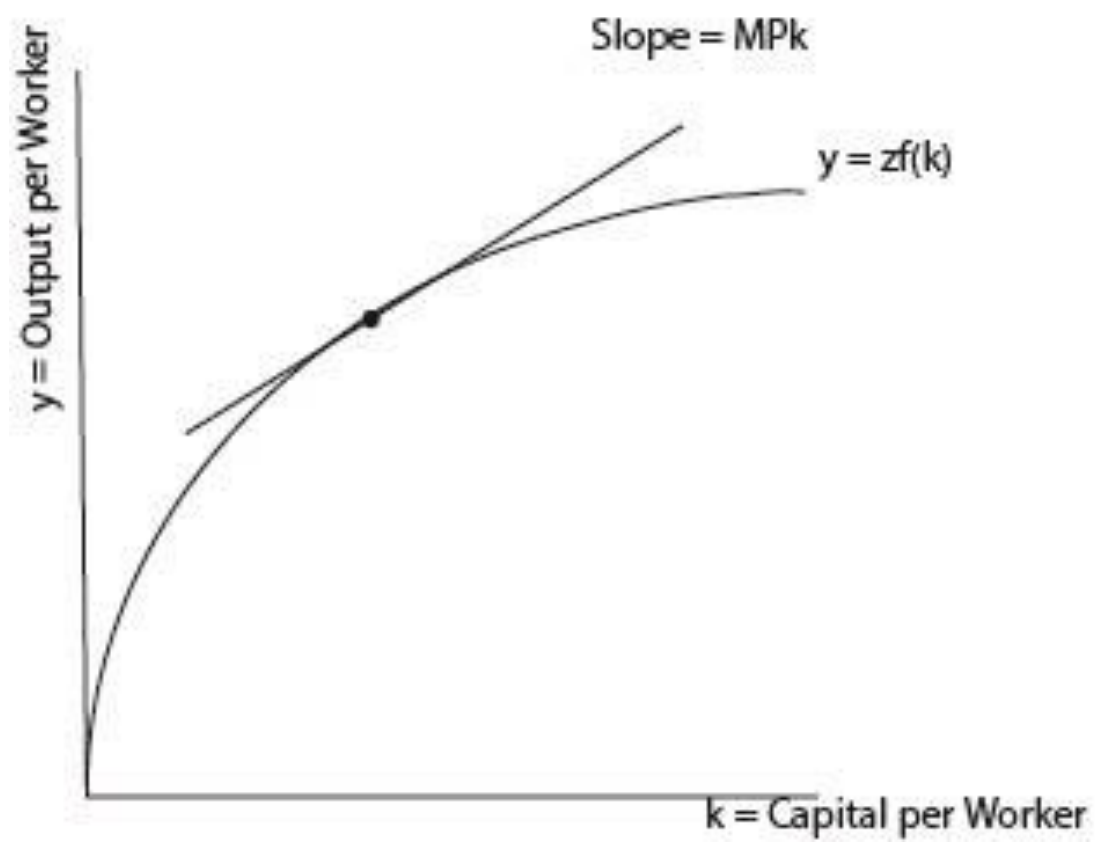




\section{Figure 2: Labor Market Equilibrium}

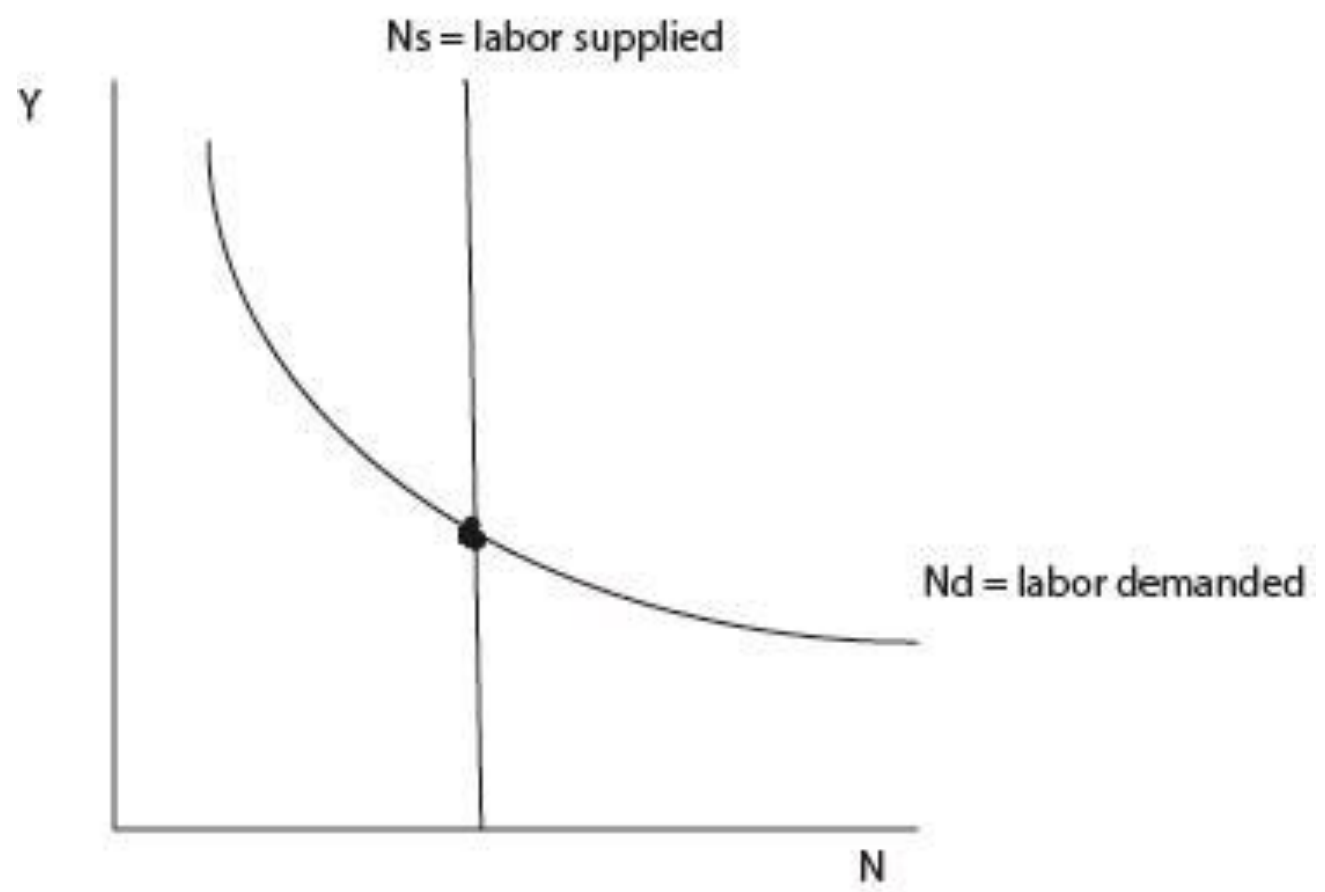


Figure 3: Determination of the Steady State Quantitity of Capital per Worker (Williamson 241)

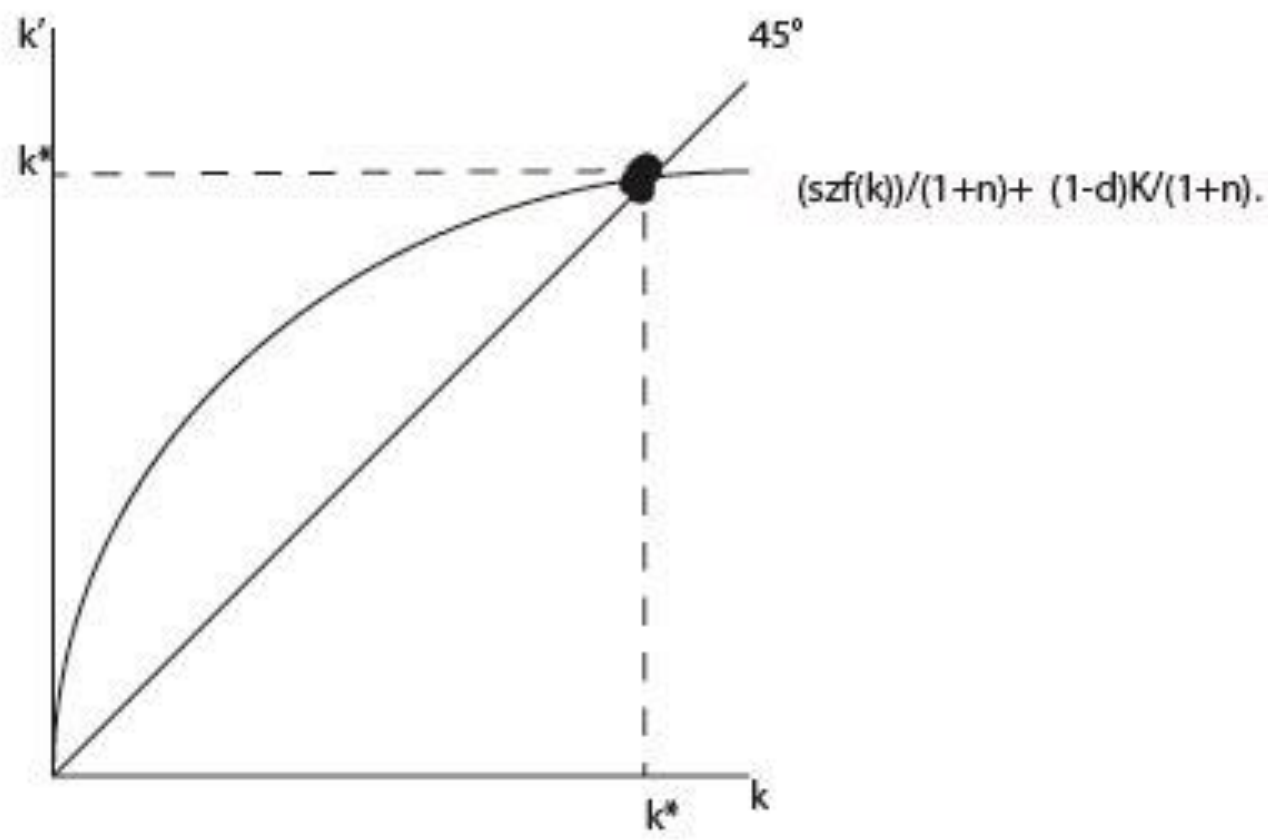


Figche 4: Increases in Total. Factor Prodoctivity (Wiluhmson 251)

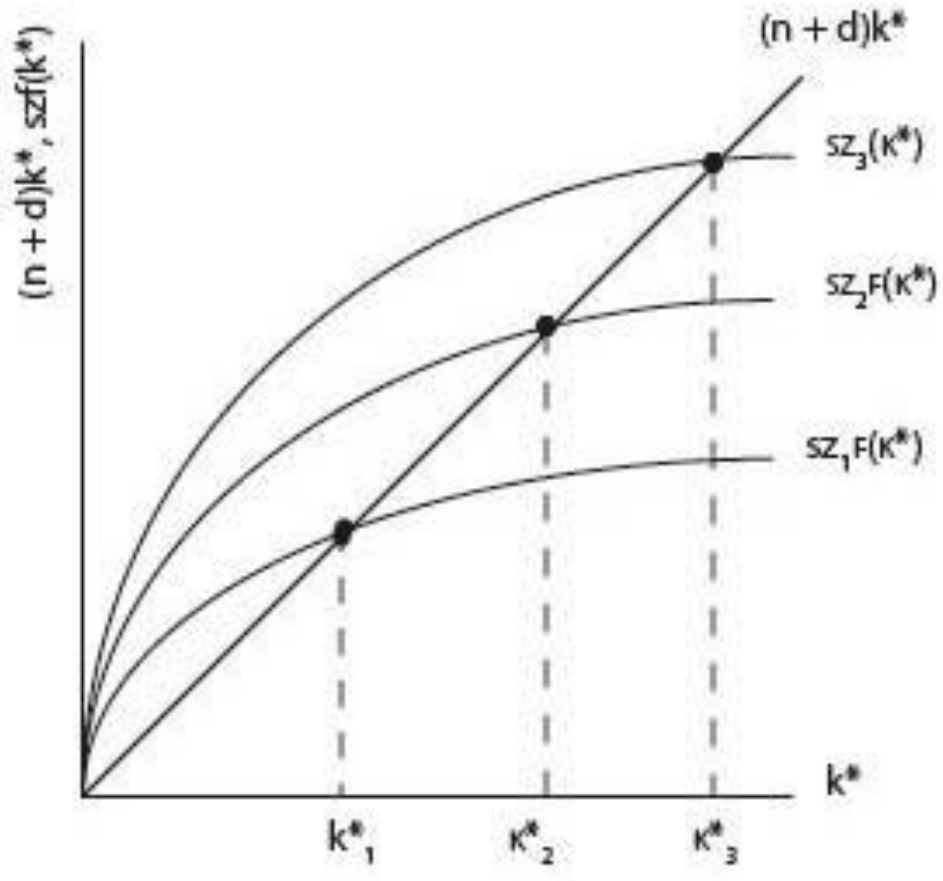

Note: $(n+d) k^{*}$ seen in Equation (15) 
Figure 5: United States Percentage Change in Real GDP per Capita and Total Factor Productivity (Gray areas indicate recessions)

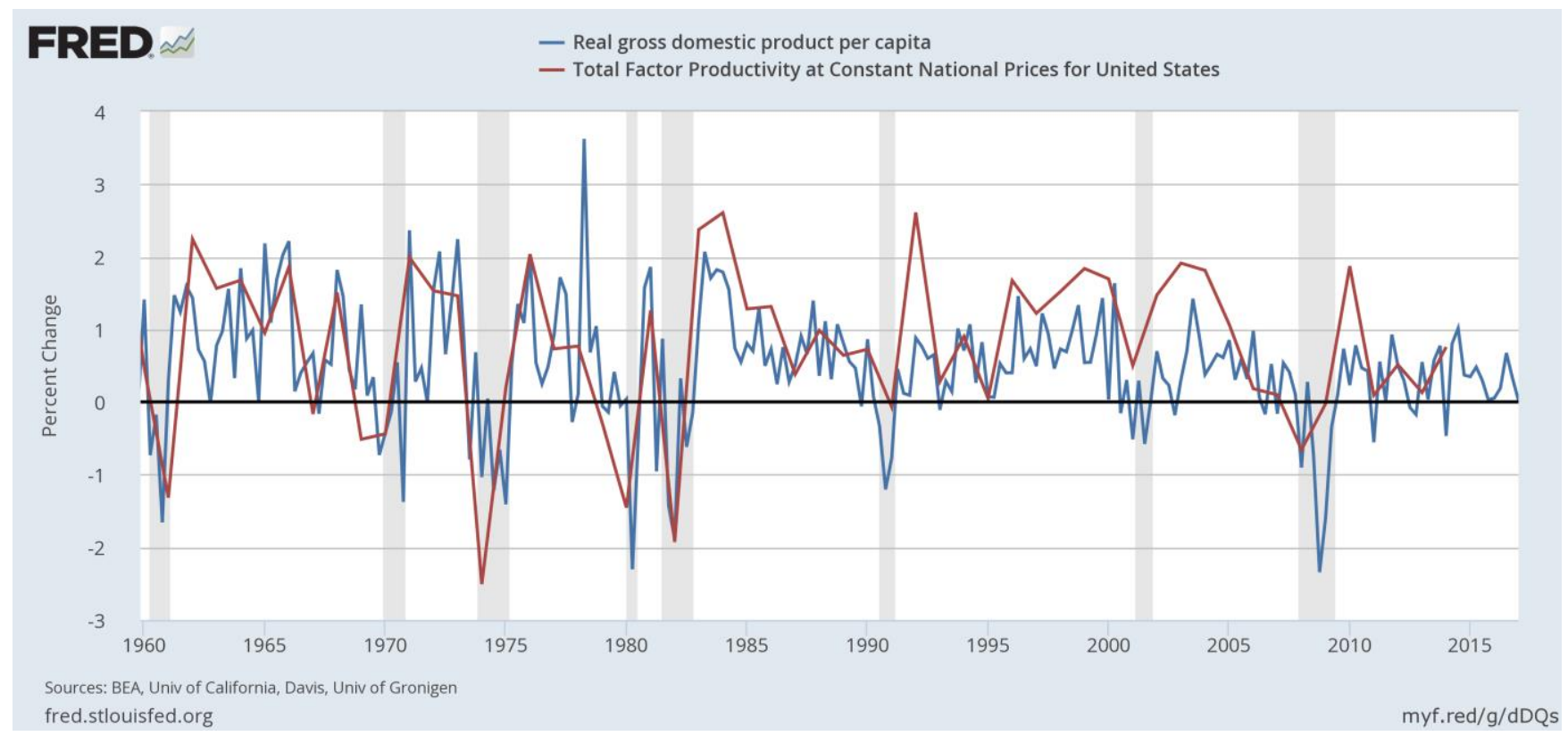

Citations:

U.S. Bureau of Economic Analysis, Real gross domestic product per capita

[A939RX0Q048SBEA], retrieved from FRED, Federal Reserve Bank of St. Louis;

https://fred.stlouisfed.org/series/A939RX0Q048SBEA, May 7, 2017.

University of Groningen and University of California, Davis, Total Factor Productivity at

Constant National Prices for United States [RTFPNAUSA632NRUG], retrieved from

FRED, Federal Reserve Bank of St. Louis;

https://fred.stlouisfed.org/series/RTFPNAUSA632NRUG, May 7, 2017. 
Figure 6: China Percentage Change in Real GDP per Capita and Total Factor Productivity

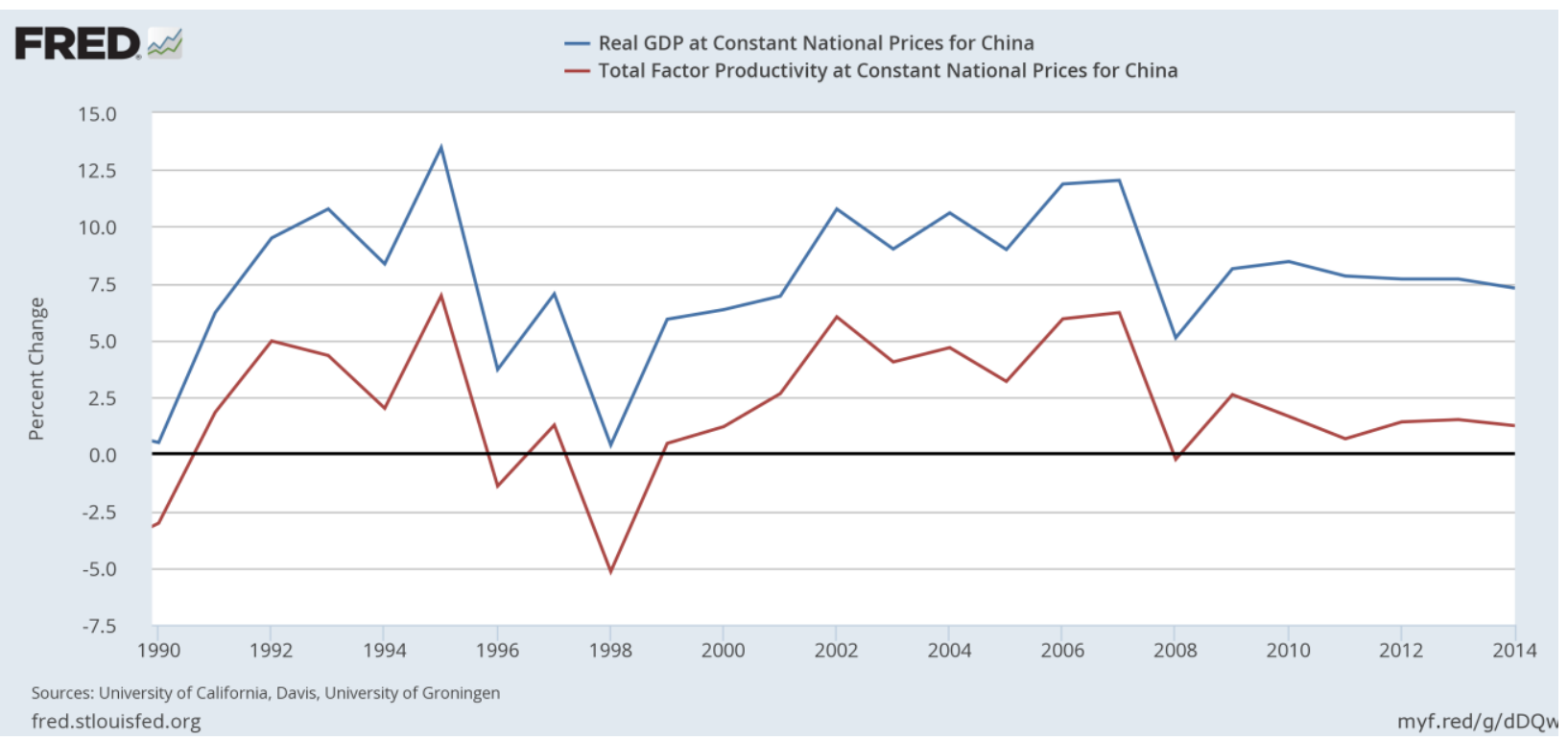

\section{Citation:}

World Bank, Constant GDP per capita for China [NYGDPPCAPKDCHN], retrieved from FRED, Federal Reserve Bank of St. Louis;

https://fred.stlouisfed.org/series/NYGDPPCAPKDCHN, May 7, 2017.

University of Groningen and University of California, Davis, Total Factor Productivity at

Constant National Prices for China [RTFPNACNA632NRUG], retrieved from FRED,

Federal Reserve Bank of St. Louis;

https://fred.stlouisfed.org/series/RTFPNACNA632NRUG, May 7, 2017. 
Figure 7: Greece Percentage Change in Real GDP per Capita and Total Factor

\section{Productivity}

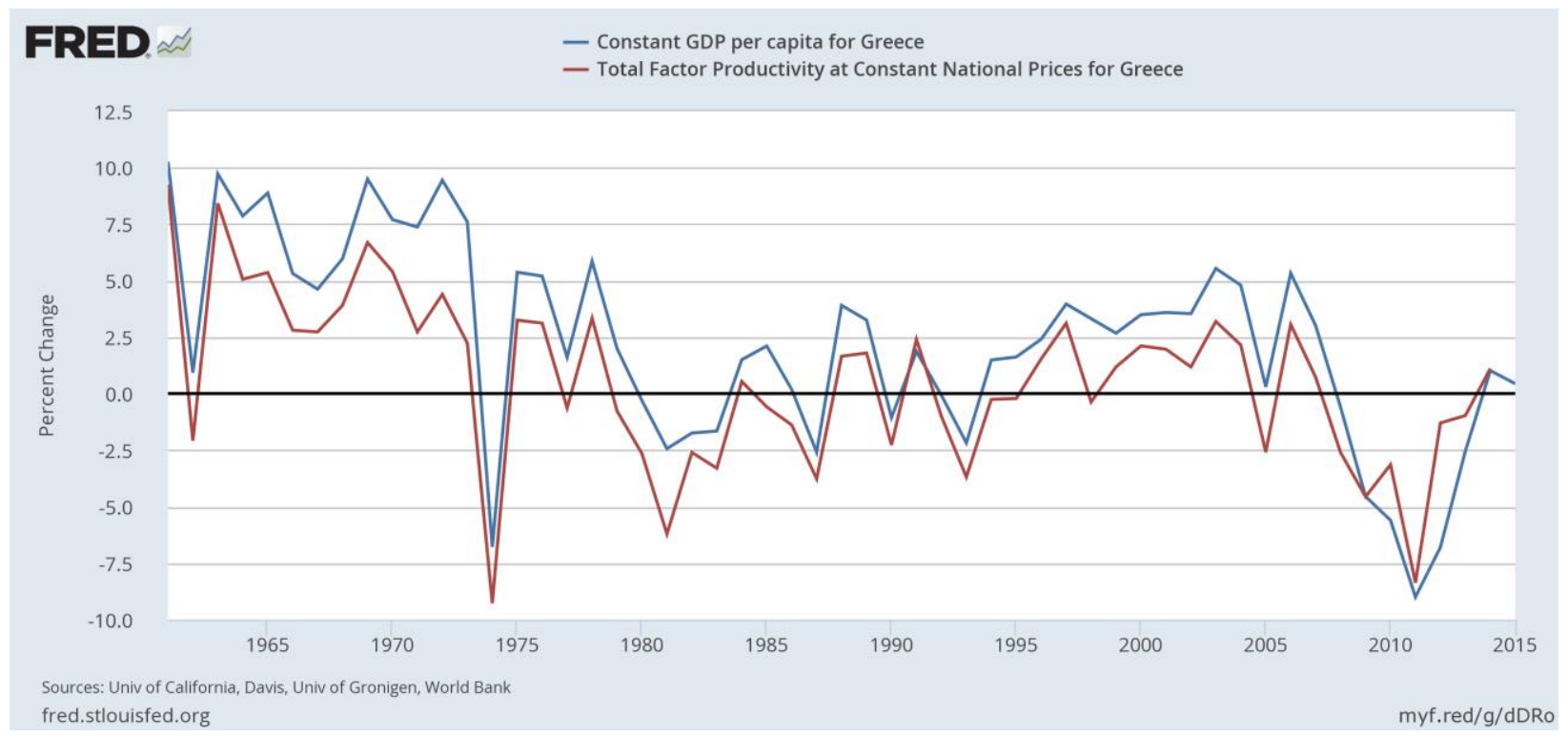

Citation:

World Bank, Constant GDP per capita for Greece [NYGDPPCAPKDGRC], retrieved from FRED, Federal Reserve Bank of St. Louis;

https://fred.stlouisfed.org/series/NYGDPPCAPKDGRC, May 7, 2017.

University of Groningen and University of California, Davis, Total Factor Productivity at

Constant National Prices for Greece [RTFPNAGRA632NRUG], retrieved from FRED,

Federal Reserve Bank of St. Louis;

https://fred.stlouisfed.org/series/RTFPNAGRA632NRUG, May 7, 2017. 


\section{References}

Solow, Robert M. "A Contribution to the Theory of Economic Growth." The Quarterly Journal of Economics 70.1 (1956): 65-94.

The Economist. "Secret Sauce." The Economist. London, 12 November 2009.

University of Groningen and University of California, Davis, Total Factor Productivity at Constant National Prices for China [RTFPNACNA632NRUG], retrieved from FRED, Federal Reserve Bank of St. Louis; https://fred.stlouisfed.org/series/RTFPNACNA632NRUG, May 7, 2017.

University of Groningen and University of California, Davis, Total Factor Productivity at Constant National Prices for Greece [RTFPNAGRA632NRUG], retrieved from FRED, Federal Reserve Bank of St. Louis; https://fred.stlouisfed.org/series/RTFPNAGRA632NRUG, May 7, 2017.

University of Groningen and University of California, Davis, Total Factor Productivity at Constant National Prices for United States [RTFPNAUSA632NRUG], retrieved from FRED, Federal Reserve Bank of St. Louis; https://fred.stlouisfed.org/series/RTFPNAUSA632NRUG, May 7, 2017

U.S. Bureau of Economic Analysis, Real gross domestic product per capita [A939RX0Q048SBEA], retrieved from FRED, Federal Reserve Bank of St. Louis; https://fred.stlouisfed.org/series/A939RX0Q048SBEA, May 7, 2017.

Williamson, Stephen D. Macroeconomics. 5th Edition. Upper Saddle River: Pearson Education, 2014. 
World Bank, Constant GDP per capita for China [NYGDPPCAPKDCHN], retrieved from FRED, Federal Reserve Bank of St. Louis; https://fred.stlouisfed.org/series/NYGDPPCAPKDCHN, May 7, 2017.

World Bank, Constant GDP per capita for Greece [NYGDPPCAPKDGRC], retrieved from FRED, Federal Reserve Bank of St. Louis; https://fred.stlouisfed.org/series/NYGDPPCAPKDGRC, May 7, 2017. 